\title{
Analisis Perlindungan Hukum Bagi Kesehatan Warga di Kawasan Pemukiman Tempat Pembuangan Akhir Tamangapa
}

\section{Analysis of Legal Protection for Citizens Health in the Tamangapa Final Disposal Area}

\author{
Indar $^{1 *}$, Nia Astarina Mas'ud ${ }^{2}$, Slamet Sampurno ${ }^{3}$, Nur Azisa $^{4}$, Haeranah $^{5}$, \\ Alwy Arifin ${ }^{6}$, Nur Inayah Ismaniar ${ }^{7}$ \\ ${ }^{1,6}$ Bagian Administrasi dan Kebijakan Kesehatan, Fakultas Kesehatan Masyarakat, \\ Universitas Hasanuddin \\ 2,3,4,5Bagian Hukum Kesehatan,Fakultas Hukum,Universitas Hasanuddin \\ ${ }^{7}$ STIKES Baramuli Pinrang \\ (*indar.sh@gmail.com/085299871826)
}

\begin{abstract}
ABSTRAK
Penelitian ini bertujuan mengetahui perlindungan hukum bagi kesehatan warga di kawasan pemukiman TPA Tamangapa dan peranan pemerintah Kota Makassar dalam menjamin kesehatan warga disekitar TPA Tamangapa. Penelitian ini berupa normatif dan empiris, yaitu meneliti data sekunder lebih dahulu, dilanjutkan dengan meneliti data primer di lapangan. Data dianalisis dan disajikan secara deskriptif kualitatif. Penegakan hukum terhadap kesehatan warga diatur dalam perundang-undangan. Hasil penelitian menunjukkan bahwa bahwa $76 \%$ warga sudah tinggal di kawasan TPA di atas 10 tahun. Sebanyak 68\% warga merasa terganggu dengan keberadaan TPA Tamangapa. Meskipun begitu gangguan kesehatan masih kurang ditemukan di masyarakat. Hasil wawancara menunjukkan bahwa 76\% warga tidak merasakan gangguan kesehatan kulit, 64\% warga tidak merasakan gangguan kesehatan saluran pernafasan, 84\% warga tidak merasakan gangguan kesehatan saluran pencernaan, 76\% warga tidak merasakan gangguan kesehatan lainnya. Untuk permasalahan keberadaan TPA Tamangapa itu sendiri, 56\% warga menyarankan TPA untuk dipindahkan.
\end{abstract}

Kata kunci: Perlindungan hukum kesehatan, TPA Tamangapa

ABSTRACT

This study aims to determine the legal protection for residents' health in the final disposal area (TPA) Tamangapa and the role of the government in Makassar for ensuring the health of residents around the landfill of Tamangapa TPA. This research was normative and empirical, ie researching secondary data firstly, followed by researching primary data directly in the field. Data were analyzed and presented by descriptive qualitative. The results show that 76\% of the residents had been living for over 10 years in Tamangapa TPA and 68\% feel disturbed by the existence of Tamangapa TPA. Although, the health problems are still lacking in the community. The interview results showed that $76 \%$ of residents did not feel skin health problems, $64 \%$ of residents did not feel respiratory health problems, $84 \%$ of residents did not feel digestive tract health problems and $76 \%$ of residents did not feel other health problems. Regarding the existence of Tamangapa TPA, 56\% of the residents suggested that the Tamangapa TPA should be moved.

Keywords: Health legal protection, TPA Tamangapa 


\section{PENDAHULUAN}

Hak atas lingkungan hidup yang baik dan sehat merupakan bagian dari hak asasi manusia sekaligus hak konstitusional warga negara. Upaya perlindungan dan pemenuhannya mengacu pada Undang-Undang Nomor 32 Tahun 2009 Tentang Perlindungan dan Pengelolaan Lingkungan Hidup selanjutnya disingkat UUPPLH. Perlindungan lingkungan mendapatkan penekanan, di samping pengelolaan lingkungan. ${ }^{1} \mathrm{Hal}$ ini berarti norma-norma perlindungan lingkungan hidup mendapatkan porsi utama dalam UUPPLH mengingat kerentanan lingkungan hidup dan kualitas hidup masyarakat oleh krisis lingkungan yang terjadi akibat kerusakan dan pencemaran lingkungan hidup.

Hak warga untuk mendapatkan lingkungan hidup yang sehat sebagai hak asasi yang dijamin dan dilindungi terdapat dalam pasal $28 \mathrm{H}$ ayat (1) Undang-Undang Dasar Negara Republik Indonesia Tahun 1945 (selanjutnya disingkat UUD NRI 1945) menyebutkan bahwa, "Setiap orang berhak hidup sejahtera lahir dan batin, bertempat tinggal, dan mendapatkan lingkungan hidup yang baik dan sehat serta berhak memperoleh pelayanan kesehatan". ${ }^{2}$ Perkembangan kota yang cepat membawa dampak pada masalah lingkungan. Perilaku manusia terhadap lingkungan akan menentukan wajah kota, sebaliknya lingkungan juga akan mempengaruhi perilaku manusia. Lingkungan yang bersih akan meningkatkan kualitas hidup. ${ }^{3}$

Namun pencemaran lingkungan merupakan masalah yang hampir ada di setiap negara baik negara berkembang maupun negara maju sekalipun. Lebih spesifik, Undang-Undang No. 36 Tahun 2009 tentang Kesehatan menyebutkan bahwa setiap kegiatan dalam upaya untuk memelihara dan meningkatkan derajat kesehatan masyarakat yang setinggi-tingginya dilaksanakan berdasarkan prinsip non diskriminatif, partisipatif, dan berkelanjutan. Sehingga setiap hal yang menyebabkan terjadinya gangguan kesehatan pada masyarakat Indonesia akan menimbulkan kerugian ekonomi yang besar bagi negara, dan setiap upaya peningkatan derajat kesehatan masyarakat juga berarti investasi bagi pembangunan negara. ${ }^{4}$ Demikian pembangunan nasional harus memperhatikan kesehatan masyarakat dan merupakan tanggung jawab semua pihak baik Pemerintah maupun ma- syarakat.

Pasal 4 dan pasal 6 UU Nomor 36 Tahun 2009 tentang Kesehatan menyebutkan bahwa setiap orang berhak atas kesehatan dan setiap orang berhak mendapatkan lingkungan yang sehat bagi pencapaian derajat kesehatan. ${ }^{4}$ Sehingga semua pihak baik dari pemerintah, pemerintah daerah dan masyarakat harus menjamin ketersediaan lingkungan yang sehat dan tidak mempunyai resiko yang buruk bagi kesehatan. Lingkungan sehat yang dimaksud yang tertuang dalam Pasal 163 ayat (3) UU Nomor 36 tahun 2009 tentang Kesehatan, lingkungan sehat harus bebas dari unsur-unsur yang menimbulkan gangguan kesehatan, antara lain: limbah cair; limbah padat; limbah gas; sampah yang tidak diproses sesuai dengan persyaratan yang ditetapkan pemerintah; binatang pembawa penyakit; zat kimia yang berbahaya; kebisingan yang melebihi ambang batas; radiasi sinar pengion dan non pengion; air yang tercemar; udara yang tercemar; dan makanan yang terkontaminasi. ${ }^{4}$ Sehingga pengelolaan limbah cair dan padat, serta pengelolaan sampah harus diatur sedemikian rupa untuk mewujudkan lingkungan sehat.

Sampah yang ada dipermukaan bumi terdiri dari beberapa yang berdasarkan sumbernya yaitu sampah yang berasal dari pemukiman penduduk, tempat umum dan tempat perdagangan, sarana layanan masyarakat milik pemerintah, industry berat dan ringan serta sampah yang dihasilkan dari pertanian. ${ }^{5}$ Khusus pengelolaan sampah diatur dalam Undang-Undang Nomor 18 Tahun 2008 tentang Pengelolaan Sampah. Pasal 5 dalam peraturan ini disebutkan bahwa Pemerintah dan pemerintah daerah bertugas menjamin terselenggaranya pengelolaan sampah yang baik dan berwawasan lingkungan. Pasal 25 ayat (1) Undang-Undang Nomor 18 Tahun 2008 diatur pula kompensasi akibat dampak negatif dari penanganan sampah yang buruk. Kompensasi yang dimaksud dapat berupa relokasi, pemulihan lingkungan, biaya kesehatan dan pengobatan, dan/atau kompensasi dalam bentuk lain. ${ }^{6}$

Perlindungan hukum yang dikemukakan oleh Soetjipto Rahardjo bahwa merupakan upaya melindungi kepentingan seseorang dengan cara mengalokasikan suatu kekuasaan kepadanya untuk bertindak dalam kepentingan tersebut. Kemudian dikemukakan bahwa salah satu sifat dan sekaligus 
merupakan tujuan dari hukum adalah memberikan perlindungan kepada masyarakat. Sehingga, perlindungan hukum terhadap masyarakat tersebut harus diwujudkan dalam bentuk adanya kepastian hukum. ${ }^{7}$ Berdasarkan pada latar belakang yang telah dipaparkan, sehingga tujuan penelitian ini untuk menganalisis perlindungan hukum bagi kesehatan warga di kawasan pemukiman Tempat Pembuangan Akhir (TPA) Tamangapa.

\section{BAHAN DAN METODE}

Jenis penelitian ini adalah deskriptif kualitatif, bersifat deskriptif karena penelitian ini dimaksudkan memberikan gambaran secara rinci, sistematis dan akurat mengenai segala sesuatu yang diteliti. Penelitian dilakukan pada Bulan Agustus sampai Bulan Desember tahun 2017. Penelitian ini diadakan di kawasan pemukiman penduduk Tempat Pembuangan Akhir Tamangapa dan Puskesmas Tamangapa. Metode pendekatan yang digunakan penulis adalah yuridis empiris yaitu cara atau prosedur yang digunakan untuk memecahkan masalah penelitian dengan meneliti data sekunder terlebih dahulu untuk kemudian dilanjutkan dengan mengadakan penelitian primer dilapangan. Instrumen penelitian berupa kuesioner yang diperoleh dari hasil wawancara kemudian dianalisis menggunakan metode statistik sederhana dengan membandingkan antara jumlah penduduk dengan jenis gangguan kesehatan yang dialami. Selain jenis gangguan kesehatan, usia mukim populasi dan tanggapan warga terhadap keberadaan TPA Tamangapa juga dianalisa. Hasil yang diperoleh dari data yang diolah kemudian ditampilkan dalam bentuk persentase.

\section{HASIL}

Kuesioner wawancara dalam penelitian ini melibatkan 25 kepala keluarga dari warga sekitar TPA Tamangapa dan warga Borong Jambu didapatkan hasil bahwa $76 \%$ warga sudah tinggal di kawasan tersebut di atas 10 tahun sementara sisanya kurang dari 10 tahun. Kesadaran warga dalam menggunakan air PDAM juga tinggi yaitu $80 \%$ dari sisanya yang masih menggunakan air sumur dalam kegiatan sehari-hari. Sebanyak $68 \%$ warga merasa terganggu dengan keberadaan TPA Tamangapa (Tabel 1).

Mengingat masa tinggal warga di kawasan

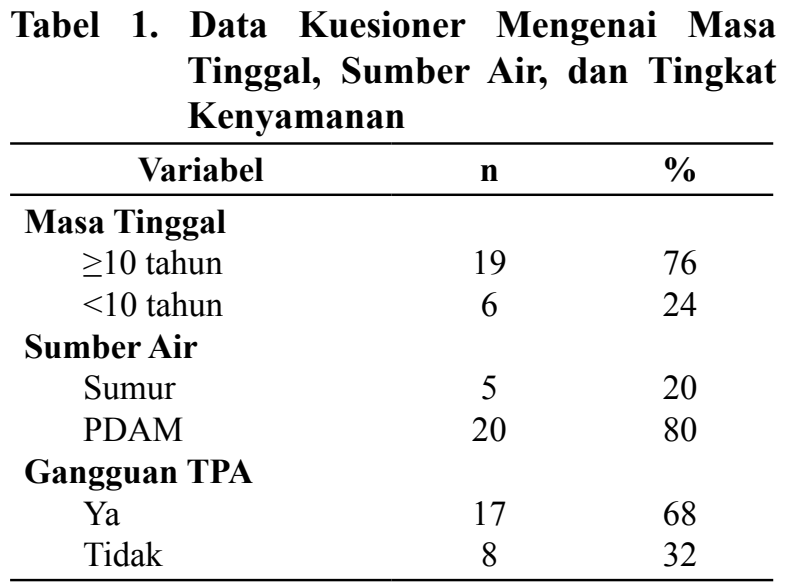

Tamangapa yang sudah menetap lebih dari 10 tahun maka ada kemungkinan bahwa warga mengalami resistensi terhadap lingkungan sekitar, sehingga sudah jarang didapati keluhan kesehatan. Namun jika terjadi gangguan kesehatan, $60 \%$ warga sudah menyadari untuk segera berobat ke puskesmas setempat. Sebanyak $60 \%$ warga juga pernah mengikuti penyuluhan yang diadakan oleh puskesmas ataupun pernah didatangi dari rumah ke rumah untuk diberikan penyuluhan oleh pihak puskesmas (Tabel 1).

Sebanyak $76 \%$ warga tidak merasakan gangguan kesehatan kulit, 64\% warga tidak merasakan gangguan kesehatan saluran pernafasan, $84 \%$ warga tidak merasakan gangguan kesehatan saluran pencernaan, $76 \%$ warga tidak merasakan gangguan kesehatan lainnya (Tabel 2). Meskipun demikian, warga tetap merasakan ketidaknyamanan mengenai pencemaran udara apalagi disaatsaat tertentu seperti saat truk sampah lewat dan musim hujan.

Permasalahan keberadaan TPA Tamangapa itu sendiri 56\% warga menyarankan TPA untuk dipindahkan, 20\% beranggapan bahwa TPA tidak perlu untuk dipindahkan melainkan alat dan prosesnya yang harus dimutakhirkan agar mengurangi dampak, sedangkan sisanya dari komunitas pemulung memilih TPA tetap seperti ini karena mata pencaharian mereka berada disana (Tabel 3).

\section{PEMBAHASAN}

Perlindungan hukum bisa berarti perlindungan yang diberikan terhadap hukum agar tidak ditafsirkan berbeda dan tidak cederai oleh aparat penegak hukum dan juga bisa berarti per- 
Tabel 2. Data Kuesioner Mengenai Gangguan Kesehatan

\begin{tabular}{lcccc}
\hline \multirow{1}{*}{\multicolumn{1}{c}{ Variabel }} & \multicolumn{2}{c}{ Ya } & \multicolumn{2}{c}{ Tidak } \\
\cline { 2 - 5 } & $\mathbf{n}$ & $\mathbf{0}$ & $\mathbf{n}$ & $\mathbf{\%}$ \\
\hline Kesehatan Kulit & 6 & 24 & 19 & 76 \\
Kesehatan Nafas & 9 & 36 & 16 & 64 \\
Kesehatan Cerna & 4 & 16 & 21 & 84 \\
Kesehatan Lain & 6 & 24 & 19 & 76 \\
\hline
\end{tabular}

Tabel 3. Saran Responden Keberadaan TPA Tamangapa Tahun 2018

\begin{tabular}{lcc}
\hline \multirow{2}{*}{ Saran } & \multicolumn{2}{c}{ Saran untuk TPA } \\
\cline { 2 - 3 } & n & \% \\
\hline Pindahkan & 14 & 56 \\
Mutakhirkan & 5 & 20 \\
Tidak ada & 6 & 24 \\
\hline
\end{tabular}

lindungan yang diberikan oleh hukum terhadap sesuatu. Hakekatnya setiap orang berhak mendapatkan perlindungan dari hukum. Demikian hampir seluruh hubungan hukum harus mendapat perlindungan dari hukum. Oleh karena itu terdapat banyak macam perlindungan hukum. Berdasarkan teori dari Philipus M. Hadjon menyatakan bahwa perlindungan hukum adalah perlindungan akan harkat dan martabat, serta pengakuan terhadap hak-hak asasi manusia yang dimiliki oleh subyek hukum berdasarkan ketentuan hukum dari kesewenangan. ${ }^{8}$

Perlindungan hukum dalam pelayanan kesehatan dan bagi rakyat terdiri dari perlindungan hukum preventif dan perlindungan hukum represif. Perlindungan hukum preventif adalah perlindungan hukum yang bertujuan untuk mencegah terjadinya sengketa. ${ }^{8}$ Sehingga upaya yang dilakukan lebih difokuskan untuk meminimalisir terjadinya masalah yang sekaligus untuk menghindari munculnya akibat dari suatu masalah. Dalam implementasinya bentuk perlindungan ini adalah dengan dibentuknya peraturan perundangundangan yang bersifat regulatif. Negara diharapkan mengaplikasikan tujuan dibentuknya peraturan perundang-undangan yakni melindungi segenap bangsa Indonesia. Bentuk perlindungan ini dapat ditemukan, di antaranya: Undang-Undang Dasar RI 1945, Undang-Undang No. 36 Tahun 2009 tentang Kesehatan, Undang-Undang No. 32 tahun 2009 tentang Perlindungan dan Pengelolaan Lingkungan Hidup.

Perlindungan hukum represif adalah per- lindungan yang bertujuan untuk menyelesaikan permasalahan atau sengketa yang timbul. ${ }^{8}$ Perlindungan ini baru akan dilakukan pada saat pelaksanaan perjanjian berlangsung. Sehingga perlindungan yang diberikan lebih ditekankan pada upaya untuk mencari penyelesaian sengketa dalam rangka mempertahankan hak-hak yang dimiliki para pihak seperti Pasal 66 Undang-Undang No. 32 Tahun 2009 tentang Perlindungan dan Pengelolaan Lingkungan Hidup, Undang-Undang No. 81 Tahun 2012 tentang Tentang Pengelolaan Sampah Rumah Tangga Dan Sampah Sejenis Sampah Rumah Tangga. ${ }^{19}$

Peraturan Perundang-Undangan mengenai Perlindungan Kesehatan bagi Warga di Kawasan Pemukiman TPA Tamangapa. Pengkajian mengenai perlindungan kesehatan bagi warga pemukiman dalam UUD 1945 diantaranya pada Pasal $28 \mathrm{H}$ ayat (1), Pasal 34 ayat (3). ${ }^{2}$ Sementara dalam UU No. 18 Tahun 2008 tentang Pengelolaan Sampah khususnya disebutkan pada pasal 4, 25, 37, 40, dan 41. Pada Pasal 4 menjelaskan bahwa pengelolaan sampah bertujuan untuk meningkatkan kesehatan masyarakat dan kualitas lingkungan serta menjadikan sampah sebagai sumber daya. Pada Pasal 25 menjelaskan bahwa pada ayat (1) Pemerintah dan pemerintah daerah secara sendiri-sendiri atau bersama-sama dapat memberikan kompensasi kepada orang sebagai akibat dampak negatif yang ditimbulkan oleh kegiatan penanganan sampah di tempat pemrosesan akhir sampah dan pada ayat 2 menjelaskan bahwa kompensasi sebagaimana dimaksud pada ayat 1 berupa: relokasi; pemulihan 
lingkungan; biaya kesehatan dan pengobatan; dan/ atau kompensasi dalam bentuk lain. ${ }^{6}$

Pasal 37 dijelaskan bahwa pada ayat 1 bahwa Organisasi persampahan berhak mengajukan gugatan untuk kepentingan pengelolaan sampah yang aman bagi kesehatan masyarakat dan lingkungan, ayat 2 menjelaskan bahwa Hak mengajukan gugatan sebagaimana dimaksud pada ayat (1) terbatas pada tuntutan untuk melakukan tindakan tertentu, kecuali biaya atau pengeluaran riil dan ayat 3 bahwa organisasi persampahan yang berhak mengajukan gugatan sebagaimana dimaksud pada ayat 1 harus memenuhi persyaratan: berbentuk badan hukum; mempunyai anggaran dasar di bidang pengelolaan sampah; telah melakukan kegiatan nyata paling sedikit 1 (satu) tahun sesuai dengan anggaran dasarnya. ${ }^{6}$

Pasal 40 ayat 1 menjelaskan bahwa pengelola sampah yang secara melawan hukum dan dengan sengaja melakukan kegiatan pengelolaan sampah dengan tidak memperhatikan norma, standar, prosedur, atau kriteria yang dapat mengakibatkan gangguan kesehatan masyarakat, gangguan keamanan, pencemaran lingkungan, dan/ atau perusakan lingkungan diancam dengan pidana penjara paling singkat 4 (empat) tahun dan paling lama 10 (sepuluh) tahun dan denda paling sedikit Rp100.000.000,00 (seratus juta rupiah) dan paling banyak Rp5.000.000.000,00 (lima miliar rupiah). ${ }^{6}$ Sedangkan pada ayat 2 menjelaskan bahwa jika tindak pidana sebagaimana dimaksud pada ayat (1) mengakibatkan orang mati atau luka berat, pengelola sampah diancam dengan pidana penjara paling singkat 5 (lima) tahun dan paling lama 15 (lima belas) tahun dan denda paling sedikit Rp100.000.000 (seratus juta rupiah) dan paling banyak Rp5.000.000.000 (lima miliar rupiah).

Pasal 41 ayat (1) juga menjelaskan bahwa pengelola sampah yang karena kealpaannya melakukan kegiatan pengelolaan sampah dengan tidak memperhatikan norma, standar, prosedur, atau kriteria yang dapat mengakibatkan gangguan kesehatan masyarakat, gangguan keamanan, pencemaran lingkungan, dan/atau perusakan lingkungan diancam dengan pidana penjara paling lama 3 (tiga) tahun dan denda paling banyak Rp100.000.000,00 (seratus juta rupiah). Pada ayat (2) menjelaskan bahwa Jika tindak pidana sebagaimana dimaksud pada ayat (1) mengakibatkan orang mati atau luka berat, pengelola sampah diancam dengan pidana penjara paling lama 5 (lima) tahun dan denda paling banyak Rp500.000.000,00 (lima ratus juta rupiah). ${ }^{6}$

Perlindungan kesehatan juga diatur dalam UU No. 32 Tahun 2009 tentang Perlindungan dan Pengelolaan Lingkungan Hidup pada pasal 3 yaitu perlindungan dan pengelolaan lingkungan hidup bertujuan untuk melindungi wilayah Negara Kesatuan Republik Indonesia dari pencemaran dan/ atau kerusakan lingkungan hidup, menjamin keselamatan, kesehatan, dan kehidupan manusia, menjamin kelangsungan kehidupan makhluk hidup dan kelestarian ekosistem, menjaga kelestarian fungsi lingkungan hidup, mencapai keserasian, keselarasan, dan keseimbangan lingkungan hidup, menjamin terpenuhinya keadilan generasi masa kini dan generasi masa depan, menjamin pemenuhan dan perlindungan hak atas lingkungan hidup sebagai bagian dari hak asasi manusia, mengendalikan pemanfaatan sumber daya alam secara bijaksana, mewujudkan pembangunan berkelanjutan dan mengantisipasi isu lingkungan global. ${ }^{1}$

Pada Pasal 47 ayat (1) bahwa Setiap usaha dan/atau kegiatan yang berpotensi menimbulkan dampak penting terhadap lingkungan hidup, ancaman terhadap ekosistem dan kehidupan, dan/ atau kesehatan dan keselamatan manusia wajib melakukan analisis risiko lingkungan hidup. Pada ayat 2 bahwa Analisis risiko lingkungan hidup sebagaimana dimaksud pada ayat (1) meliputi: pengkajian risiko, pengelolaan risiko; dan/atau komunikasi risiko. Pada Pasal 66 juga menjelaskan bahwa setiap orang yang memperjuangkan hak atas lingkungan hidup yang baik dan sehat tidak dapat dituntut secara pidana maupun digugat secara perdata. ${ }^{1}$

Undang-Undang RI Nomor 32 Tahun 2009 Pasal 98 ayat (1) bahwa Setiap orang yang dengan sengaja melakukan perbuatan yang mengakibatkan dilampauinya baku mutu udara ambien, baku mutu air, baku mutu air laut, atau kriteria baku kerusakan lingkungan hidup, dipidana dengan pidana penjara paling singkat 3 (tiga) tahun dan paling lama 10 (sepuluh) tahun dan denda paling sedikit Rp3.000.000.000,00 (tiga miliar rupiah) dan paling banyak Rp10.000.000.000,00 (sepuluh miliar rupiah). Pada ayat (2) bahwa apabila perbuatan sebagaimana dimaksud pada ayat (1) 
mengakibatkan orang luka dan/atau bahaya kesehatan manusia, dipidana dengan pidana penjara paling singkat 4 (empat) tahun dan paling lama 12 (dua belas) tahun dan denda paling sedikit Rp 4.000.000.000,00 (empat miliar rupiah) dan paling banyak Rp12.000.000.000,00 (dua belas miliar rupiah). Pada ayat (3) bahwa Apabila perbuatan sebagaimana dimaksud pada ayat (1) mengakibatkan orang luka berat atau mati, dipidana dengan pidana penjara paling singkat 5 (lima) tahun dan paling lama 15 (lima belas) tahun dan denda paling sedikit Rp5.000.000.000,00 (lima miliar rupiah) dan paling banyak Rp15.000.000.000,00 (lima belas miliar rupiah). ${ }^{1}$

Pasal 99 ayat (1) bahwa setiap orang yang karena kelalaiannya mengakibatkan dilampauinya baku mutu udara ambien, baku mutu air, baku mutu air laut, atau kriteria baku kerusakan lingkungan hidup, dipidana dengan pidana penjara paling singkat 1 (satu) tahun dan paling lama 3 (tiga) tahun dan denda paling sedikit Rp1.000.000.000,00 (satu miliar rupiah) dan paling banyak Rp3.000.000.000,00 (tiga miliar rupiah). Pada ayat (2) Apabila perbuatan sebagaimana dimaksud pada ayat (1) mengakibatkan orang luka dan/atau bahaya kesehatan manusia, dipidana dengan pidana penjara paling singkat 2 (dua) tahun dan paling lama 6 (enam) tahun dan denda paling sedikit Rp2.000.000.000,00 (dua miliar rupiah) dan paling banyak Rp6.000.000.000,00 (enam miliar rupiah). Pada ayat (3) Apabila perbuatan sebagaimana dimaksud pada ayat (1) mengakibatkan orang luka berat atau mati, dipidana dengan pidana penjara paling singkat 3 (tiga) tahun dan paling lama 9 (sembilan) tahun dan denda paling sedikit Rp3.000.000.000,00 (tiga miliar rupiah) dan paling banyak Rp9.000.000.000,00 (sembilan miliar rupiah). ${ }^{1}$

Perlindungan kesehatan juga diatur dalam Peraturan Pemerintah Republik Indonesia Nomor 81 Tahun 2012 Tentang Pengelolaan Sampah Rumah Tangga dan Sampah Sejenis Sampah Rumah Tangga yaitu pada pasal 11 yang menjelaskan bahwa setiap orang berhak mendapatkan pelayanan dalam pengelolaan sampah secara baik dan berwawasan lingkungan dari Pemerintah, pemerintah daerah, dan/atau pihak lain yang diberi tanggung jawab untuk itu, berpartisipasi dalam proses pengambilan keputusan, penyelenggaraan, dan penga- wasan di bidang pengelolaan sampah, Memperoleh informasi yang benar, akurat, dan tepat waktu mengenai penyelenggaraan pengelolaan sampah, mendapatkan pelindungan dan kompensasi karena dampak negatif dari kegiatan tempat pemrosesan akhir sampah, dan memperoleh pembinaan agar dapat melaksanakan pengelolaan sampah secara baik dan berwawasan lingkungan. ${ }^{9}$

Penerapan perlindungan kesehatan bagi warga di kawasan pemukiman TPA Tamangapa dilakukan oleh layanan Puskesmas setempat yaitu Puskesmas Tamangapa ataupun Pustu (Puskesmas Pembantu) yang dikoordinir oleh Kepala Puskesmas beserta jajaran staff tenaga kesehatan dalam memberikan penyuluhan, layanan home care 24 jam, sampai pembagian obat-obatan. Sesuai dengan hasil wawancara dengan salah seorang staf tenaga kesehatan yaitu $\mathrm{Bu} I$ pada tanggal 7 Desember 2017 yang memaparkan bahwa program puskesmas untuk peningkatan derajat kesehatan warga adalah membina warga yaitu berupa penyuluhan di posyandu untuk pencegahan penyakit, misalnya di TPA ada yang mengambil makanan langsung dari sampah, maka diadakanlah penyuluhan dari rumah ke rumah karena mereka/komunitas pemulung susah dikumpulkan karena dalam mencari nafkah/memulung mereka membagi per shift. Penyuluhan ini dilakukan agar masyarakat tidak langsung mengambil makanan dari TPA, begitu juga cara cuci tangan yang baik, pola hidup bersih dan sehat. Sementara untuk anak-anak sekolah dan pemulung juga diajarkan 10 indikator pola hidup bersih dan sehat/PHBS, yaitu: persalinan ditolong oleh tenaga kesehatan, memberi bayi ASI ekslusif, menimbang bayi dan balita setiap bulan, menggunakan air bersih, mencuci tangan dengan air bersih dan sabun, menggunakan jamban sehat, memberantas jentik di rumah, makan buah dan sayur setiap hari, melakukan aktifitas fisik setiap hari, tidak merokok di dalam rumah.

Dikatakan juga bahwa akibat pola hidup tidak sehat khususnya mengambil langsung makanan dari TPA kadang ada yang datang berobat muntah sampai mengeluarkan cacing. Jadi dibuatlah pula layanan pembagian obat cacing secara berkala dan hasilnya memang sudah ada peningkatan. Bagaimana tidak, ditimbunan sampah itu ada makanan sisa restoran, buah sudah busuk sebagian, tepung terigu yang kadaluarsa tapi 
mirisnya diambil juga untuk dikonsumsi oleh sebagian komunitas pemulung dengan alasan lapar. Susah juga melarangnya karena mereka sudah resisten, makan pun ditumpukan sampah dan tidak mengalami diare.

Pemerintah setiap tahun juga telah memprogramkan pembagian obat cacing untuk anak kelas 1-6 di tingkat Sekolah Dasar. Tingkat kesadaran masyarakat untuk datang berobat ke puskemas juga sudah meningkat, jadi penanganan bisa cepat. Padahal sebelumnya masih ada yang mengandalkan dukun/sanro untuk berobat. Terdapat program home care juga di layanan 112 , setiap ada keluhan baik siang ataupun malam segera dilayani bahkan jika warga terebut tidak punya kartu kesehatan semisal BPJS.

Penelitian yang dilakukan Astuti Nur Fadillah yang berjudul Penegakan Hukum Lingkungan terhadap Perubahan Kualitas Air Tanah di TPA Tamangapa yaitu bahwa penegakan hukum lingkungan dalam memelihara kualitas air tanah di TPA Tamangapa telah berjalan dengan efektif. Penegakan hukum demikian ditopang dengan diterbitkan aturan-aturan administratif dibidang kualitas air tanah dan tempat pengelolaan sampah serta adanya persyaratan dan perizinan dan amdal. Instrumen hukum perdata menyediakan solusi penyelesaian sengketa apabila dikemudian hari timbul kerugian atas perubahan kualitas air tanah di sekitar TPA yaitu berupa ganti kerugian. Instrumen hukum pidana menjadi ultimatum remedium dalam upaya terakhir ketika hukum administratif dan hukum perdata tidak efektif lagi. ${ }^{10}$

Dampak atas keberadaan TPA Tamangapa di kawasan pemukiman penduduk. Keberadaan TPA ini tentunya sangat mempengaruhi lingkungan disekitar TPA tersebut. Dampak TPA terhadap lingkungan sekitar tersebut ada yang negatif dan ada juga yang positif. Perubahan lingkungan alam dalam rangkaian prosesnya akhirnya mengakibatkan perubahan sosial pada masyarakan beserta dampak-dampak yang ditimbulkannya sebagai wujud adaptasi mereka terhadap lingkungan. Perubahan sosial tersebut antara lain adalah: perubahan mata pencaharian, munculnya perumahan kumuh di sekitar TPA, kemiskinan komunitas pemulung, penurunan kualitas hidup.

\section{KESIMPULAN DAN SARAN}

Berdasarkan hasil penelitian yang telah dilakukan, disimpulkan bahwa perlindungan hukum terhadap kesehatan warga di kawasan pemukiman sekitar TPA Tamangapa diatur dan dilindungi dengan adanya peraturan-peraturan tentang kesehatan mulai dari yang termuat dalam UUD NRI 1945, UU RI No. 4 Tahun 1992 tentang Perumahan dan Pemukiman, UU RI No. 18 Tahun 2008 tentang Pengelolaan Sampah, UU RI No. 36 Tahun 2009 tentang Kesehatan, serta UndangUndang RI No. 32 Tahun 2009 tentang Perlindungan dan Pengolalaan Lingkungan Hidup.

Penerapan perlindungan kesehatan bagi warga di kawasan pemukiman TPA Tamangapa dilakukan oleh layanan puskesmas setempat yaitu Puskemas Tamangapa ataupun Pustu (Puskesmas Pembantu) yang dikoordinir oleh Kepala Puskesmas beserta jajaran staff tenaga kesehatan dalam menjalankan programnya. Kenyataan yang didapatkan berupa dampak atas keberadaan TPA Tamangapa di kawasan pemukiman penduduk adalah meningkatnya jumlah kasus gangguan kesehatan. Sebagian besar dari mereka telah menetap dalam waktu yang lama. Para warga telah meningkat kesadarannya akan kesehatan diri dan keluarga dengan mengunjungi Puskesmas jika mengalami sakit dan kemudian mengikuti penyuluhan kesehatan.

Perlakuan terhadap TPA Tamangapa sebagian warga menyarankan TPA untuk dipindahkan, juga disarankan pemerintah agar terus mengawasi pelaksanaan akan peraturanperaturan mengenai kesehatan khususnya bagi warga di kawasan pemukiman TPA Tamangapa. Sebaiknya bekerja sama dengan pihak dari UPTD TPA Tamangapa dalam mengkoordinir komunitas pemulung agar lebih terorganisir agar dapat dengan mudah diberikan penyuluhan mengenai keselamatan selama bekerja. Penulis berharap adanya penelitian lebih lanjut khususnya penelitian terhadap perlindungan hukum bagi kesehatan warga di kawasan pemukiman di daerah tersebut.

Himbauan usaha pengelolaan sampah salah satu upaya untuk dapat mereduksi volume timbunan sampah yaitu menghimbau untuk menerapkan program 3R (Reuse, Reduce, Recycle) kepada masyarakat sebelum sampah-sampah tersebut berakhir di TPA. Hal ini terlihat dalam pengenalan 
dini konsep 3R tersebut di sekolah-sekolah. Namun peran serta dan kesadaran masyarakat dalam pengelolaan sampah melalui program $3 \mathrm{R}$ itu masih terasa kurang. Melalui program ini, warga masyarakat dihimbau agar sampah tidak dijadikan musuh tetapi sebagai sahabat karena sampah organik bisa dijadikan pupuk kompos dan sampah anorganik bisa dikelola menjadi beraneka ragam benda kerajinan.

\section{DAFTAR PUSTAKA}

1. Undang-Undang No. 32 Tahun 20109. Tentang Perlindungan dan Pengolalaan Lingkungan Hidup.

2. Undang-Undang Dasar Tahun 1945.

3. Alkadri, Muchdie, Suhandojo. Tiga Pilar Pengembangan Wilayah, Sumber Daya Alam, Sumber Daya Manusia, Teknologi. Jakarta: Direktorat Kebijaksanaan Teknologi untuk Pengembangan Wilayah, Badan Pengkajian dan Penerapan Teknologi; 1999.

4. Undang-Undang No. 36 Tahun 2009. Tentang Kesehatan.

5. Sumantri A. Kesehatan Lingkungan. Jakarta: Kencana Prenada Media Group; 2010.

6. Undang-Undang No 18 Tahun 2008. Tentang Pengelolaan Sampah.

7. Rahardjo S. Permasalahan Hukum di Indonesia. Bandung: Alumni; 1983.

8. Hadjon PM. Perlindungan Hukum Bagi Rakyat di Indonesia. Surabaya: Bina Ilmu; 1987.

9. Peraturan Pemerintah Republik Indonesia No. 81 Tahun 2012. Tentang Pengelolaan Sampah Rumah Tangga dan Sampah Sejenis Sampah Rumah Tangga.

10. Fadillah AN. Penegakan Hukum Lingkungan Terhadap Perubahan Kualitas Air Tanah di TPA Tamangapa. [Tesis]. Makassar: Universitas Hasanuddin; 2017. 